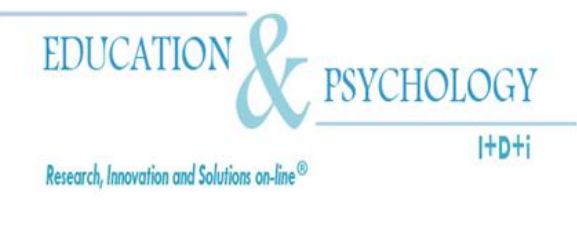

\title{
Nonverbal communication in classroom interactions: A pedagogical perspective of touch
}

\author{
Panagiotis J. Stamatis \\ Department of Sciences of Preschool Education and Educational Design \\ (TEPAES), University of the Aegean, Rhodes
}

\section{Greece}

Correspondence: Dr. Panagiotis J. Stamatis. University of the Aegean, GR-851 01 DAMATRIA, RHODES, Greece. E-mail: stamatis@rhodes.aegean.gr

(C) Education \& Psychology I+D+i and Editorial EOS (Spain) 


\begin{abstract}
This paper begins by exploring touch as "tactile perception" dimension, which means what human hands could achieve, especially considering the important role of skin receptors. The author moves forward to a description of children's necessity for contact as well as to their touch disorders. Following descriptions further clarify these items in the context of human touching behavior. The aim of the present article is to underline the touch dimensions, which needs clarification for the benefit of the development of an appropriate touching behavior between teachers and children, as a strategy of children pedagogical support and as a factor for improvement in classroom interactions according to attachment theory. The review of the professional literature relevant to our research question helps us contextualize the educational value of touching as an educative strategy that contributes to the improvement of the classroom atmosphere. This is because appropriate touching in early childhood relates to the development of positive feelings both in teachers and students, which is remarkable and exceptionally useful for any educational interaction that is expressed into the teaching framework or the educational environment.
\end{abstract}

Keywords: Touch, nonverbal communication, touching behavior, classroom interaction, tactile perception.

Received: 08/28/11 Initial acceptance: 09/15/11 Final acceptance: 11/03/11 


\section{Comunicación no verbal en las interacciones de aula: una perspectiva pedagógica sobre el contacto físico}

\section{Resumen}

El presente articulo comienza el tema del tacto en cuanto "percepción táctil", es decir, lo que se puede palpar con las manos, tomando en cuenta, especialmente, los receptores táctiles de la piel. El autor pasa luego a describir la importancia del contacto físico en la infancia, así como de sus alteraciones. Estos aspectos son gradualmente descritos con el fin de poner en claro en qué consiste el sentido del tacto y a qué podría estar relacionado en el marco de la conducta táctil en el comportamiento del ser humano. El objetivo que se propone el presente artículo consiste en subrayar el papel que desempeña el sentido del tacto, el cual pone de relieve los beneficios derivados de un desarrollo apropiado del comportamiento táctil en la relación maestro-alumno como una estrategia para prestar ayuda pedagógica, así como un factor que se puede usar para mejorar las habilidades de interacción en la sala de clases conforme a la teoría del apego. Se hace un repaso a la literatura científica dedicada al estudio sobre el enfoque científico apropiado del valor del tacto pedagógico como una estrategia educativa que contribuye a mejorar la atmósfera en la sala de clases. Es por ello que un tacto adecuado en la edad temprana está relacionado con un desarrollo de sentimientos positivos en maestros y alumnos, los cuales pueden resultar sumamente útiles en todos los aspectos de las relaciones educativas en el marco de la enseñanza o del medio educativo.

Palabras Clave: Tacto, comunicación no verbal, comportamiento táctil, interacción en la sala de clases, percepción táctil.

Recibido: 28/08/11 Aceptación inicial: 15/09/11 Aceptación final: 03/11/11 


\section{Introduction}

The hunger for safe and affectionate human contact comfort may be more intense than our hunger for food and almost as necessary to our survival as to other species. Over the last few decades, researchers have clearly demonstrated that a failure to receive "adequate" amounts of somatosensory stimulation (touch) may result in depression, anxiety, violence, substance abuse, inability to adequately parent a child, inability to adequately engage in healthy adult relationships, and, in infancy, failure to thrive, or perhaps even in death (Field, 2001). Beyond the declared neuropsychological consequences of the deprivation of physical contact on humans, similar questions on the educational value of touching remain unanswered among the scientific community despite the various attempts that have been made over the last years (Stamatis \& Kontakos, 2008; Simonds \& Cooper, 2011).

Even in our modern society, which is characterized by the lack of trust, suspiciousness and alienation between people, would it be perhaps possible to allow the use of touch, though, under certain conditions, between teachers and students in the educational process, hoping that it will induce better academic performance on students or that it will improve psycho emotional factors, which are responsible for their smooth adjustment in the school environment and the development of interpersonal relationships. The neuropsychological aspect of touching that this paper attempts to present also enables teachers to be informed and sensitized about its educational utilization from a pedagogical perspective, providing theoretical and practical reflections concerning relevant scientific and professional questions.

\section{The origins of touch by a neuropsychological perspective}

Touch is our most social sense. Unlike sight, hearing, smell, and taste, which can generally be autonomous, touch typically implies an interaction with another person. Although touch is extremely important for social interactions, the term is rarely used in books on communication skills. Nevertheless, a lot of research studies (Field, 2001; Richmont \& McCroskey, 2000) conducted on touch as communication have focused on its wide variability by gender, age, class, and culture. 
Touch constitutes a nonverbal communication procedure. When Demosthenes was asked which the first part of an oratory was, he answered, "action"; and which the second was, he replied, "action"; and which the third was, he still answered, "action". People tend to believe in actions more than in words! Have you ever heard anyone say, "His actions spoke so loudly, I couldn't hear what he said"? Have you ever wondered whether anyone has said this about you? What we do is a means of communication, subject to interpretation by others. Have you ever stopped to think that even failure to act is a way of communicating?

Today, many researchers are concerned with the information exchanged by communication that is independent of and different from verbal information; namely, the nonverbal communication. Verbal communication is managed by speech and language which is not the case with nonverbal communication. Communication is the transfer of information from one person to another. Most of us spend about 75 percent of our waking hours communicating our knowledge, thoughts, and ideas to others. However, most of us fail to realize that a great deal of our communication is of a nonverbal form as opposed to the oral and written forms. Nonverbal communication includes facial expressions, eye contact, tone of voice, body posture and gestures, and positioning within groups. It may also include the way we wear our clothes or the silence we keep. In person-to-person communication our messages are simultaneously sent to two levels. If the nonverbal cues and the spoken message are incongruous, the flow of communication is hindered. Whether the previous statement is right or wrong, the receiver of the communication tends to base the intentions of the sender on the nonverbal cues he receives.

Focusing our research topic, we need to bear in mind the reasons that make touch so critical for human beings and especially about how touch can be expected to be felt as a sense in our body. In other words, what is the role of hand for touching? First of all, hands relate to "tactile perception", which refers to the ability to acquire information about objects with the hands and to discriminate and recognize objects by handling them, as this is opposed to looking at them (Bushnell \& Boudreau, 1993). Second, it could be claimed that hands contribute to learning, if it is kept in mind that a primary somatosensory cortex is the best candidate as the neural substrate for the topography of learning. Somatosensory cortex conveys sensory information to multiple motor centres likely to be involved in gap-crossing (Harris, Petersen \& Diamont, 1999). In spite of the fact that research into the sensation of 
touch has a long history, there is a profound interest in understanding how information about objects we touch is presented in both the peripheral and central divisions of the nervous systems and how the mechanisms of tactile sensation can relate to tactile perception. In addition, humans can detect extremely fine textures composed of 50 nanometers high parallel bars etched on mere porcelain plates. Neurophysio-logical recordings indicate that, when such fine textures strike on the finger pad skin, the fingerprint ridges vibrate and cause Pacinian Corpuscles to respond, thus enabling the detection of the micro texture (Elias \& Saucier, 2005).

Lederman and Klatzky (1987) have studied hand movements while somebody tries to estimate physical properties and classified their findings according to Table 1 . We have done another classification of tactile perception focused on the hand ability to recognize material properties.

Table 1. Hand movements while somebody tries to estimate physical properties (Lederman \& Klatzky, 1987).

\begin{tabular}{cccc}
\hline Hand movement & Object property & Hand movement & Object property \\
\hline Static contact & Temperature & Enclosure & Volume/Size \\
Lateral motion & Texture & Pressure & Hardness \\
Unsupported holding & Weight & Contour following & Exact shape \\
\hline
\end{tabular}

Table 2 represents our classification (Stamatis, 2005), keeping in mind that the tactile perception of objects results from the combined activity of the individual tactile channels (Granit, 1975). Where is the secret of all hand perceived abilities? This is very well covered inside the skin and relates to sensory receptors or nerve endings. There are so many endings as there are nerve fibres. Nerve fibres attached to different types of skin receptors either continue to discharge during a stimulus ("slowly-adapting") or respond only when the stimulus starts and sometimes when a stimulus ends ("rapidly-adapting"). In other words, slowly-adapting nerve fibres send information about ongoing stimulation; rapidly-adapting nerve fibres send information related to changing stimuli. The Pacinian corpuscle receptor is a classic example of a rapidly-adapting type receptor. The Ruffini nerve ending is a slowlyadapting type receptor (Zillmer, Spiers \& Culbertson, 2007). 
Table 2. Tactile stimuli while somebody tries to estimate material properties (Stamatis, 2005).

\begin{tabular}{|c|c|c|c|}
\hline Solid & Material properties & Liquid & Material properties \\
\hline Temperature & $\begin{array}{l}\text { warm, cold, cool, frozen, } \\
\text { tepid, hot }\end{array}$ & Temperature & $\begin{array}{l}\text { warm, cold, cool, } \\
\text { frozen, tepid, hot }\end{array}$ \\
\hline Structure & $\begin{array}{c}\text { tough, smooth, compact, } \\
\text { vacuum }\end{array}$ & Fluidity & $\begin{array}{l}\text { fluid, viscid, viscosity, } \\
\text { cream }\end{array}$ \\
\hline $\begin{array}{l}\text { Quantity - } \\
\text { Weight }\end{array}$ & $\begin{array}{l}\text { heavy, light, much, a little, } \\
\text { some, enough }\end{array}$ & & \\
\hline $\begin{array}{l}\text { Texture- } \\
\text { Friction }\end{array}$ & $\begin{array}{l}\text { glossy, coarse, relief, } \\
\text { inculcative }\end{array}$ & & \\
\hline Quality & $\begin{array}{l}\text { good, worthless, velvety, } \\
\text { fluffy, knitting, bouncing, } \\
\text { time worn }\end{array}$ & & \\
\hline Material & $\begin{array}{l}\text { metal, wool, wood, glass, } \\
\text { plastic, paper, textile }\end{array}$ & & \\
\hline Shape & $\begin{array}{l}\text { cylinder, triangle, square, } \\
\text { circular, globular, flat, } \\
\text { rumply, ruffly, semi- } \\
\text { undone (semi-destroyed), } \\
\text { bluff, broad, hollow, } \\
\text { convexo, concave, curved }\end{array}$ & & \\
\hline Volume & $\begin{array}{c}\text { voluminous, big, small, } \\
\text { deep, shallow }\end{array}$ & Air & Material properties \\
\hline Pressure & $\begin{array}{l}\text { sharp, pointed, prickly, } \\
\text { cuspidal }\end{array}$ & Flow & $\begin{array}{l}\text { movement, } \\
\text { fluctuation, wind }\end{array}$ \\
\hline $\begin{array}{l}\text { Trent - } \\
\text { Resistance - } \\
\text { Durability }\end{array}$ & $\begin{array}{l}\text { breakage, cut, distention, } \\
\text { pressurable }\end{array}$ & $\begin{array}{l}\text { Tension - } \\
\text { Pressure }\end{array}$ & blow, compression \\
\hline
\end{tabular}

It is obvious that the skin is critical to the human perceptual ability. Skin is the external brain and nervous system of the body. It derives from exactly the same embryological layer as the internal brain and spinal cord, both of which are very closely interrelated. All the messages the skin receives must go to the internal brain, the brain then sends the message back to the skin and to any other organ of the body. These are not just theories; they are observable facts, strongly related to touch. It is not easy to understand that touch can make all the difference to another human being; it is sometimes literally a difference of life or death (Montagu, 1994). 


\section{Pedagogical perspective of touch: a short literature review}

Principles of attachment theory are critical for pedagogical perspective of touch. Those principles have been used to explain adult social behaviors, including mating, social dominance and hierarchical power structures, group coalitions, and negotiation of reciprocity and justice. Also, have been used to design parental care training, and have been particularly successful in the design of child abuse prevention programs (Bugental, Ellerson, Rainey, Lin \& Kokotovic, 2002).

Moreover, research has indicated that inadequate touch early on in life and again in puberty could contribute to violent behavior in adulthood (Prescott, 1990). Cultures, where more physical affection was shown to young children, had lower incidences of adult physical violence and vice-versa. A lower incidence of violence has been shown to French rather than to American children. This could be the explanation of the differences in the intercultural communication (Jourard, 1966). Another possible explanation can be that children who are touched less by their parents and received physical punishment by their caregivers or teachers demonstrates more negative interactions (Field, 1999).

A mounting number of scientific studies provide the biological microscopic view of the etiology of particularly serious human problems. In our current state of scientific investigations there is no doubt that touch deprivation results in the deterioration of formerly healthy brain tissue which, in turn, leads to sadly predictable deficits in health, behavior, emotions, and relationships (Hatfield, 1994).

Additionally, Prescott (1990) found that societies, which considered low in affectionate touch is the most violent on this fragile planet. A paucity of brain nourishing touch causes neurological atrophy and increases violence towards others, property, and self. The most deprived and violent individuals in these societies prey on the weakest and most vulnerable of its members, e.g., women and children, and, in almost all cases, inflict upon their victims "touch trauma" in the forms of physical abuse, sexual manipulation and sexual violence (Hatfield, 1994).

Touch is the most important of all senses. It "turns on" sight, hearing, touch, smell, and taste. It stimulates language and communication. It promotes bond and attachment, is a 
remedy for colic, constipation, sleeping disorders, tooth pains, behavior problems and the autism spectrum. It helps children with Down syndrome, genetic disorders and with high tone cerebral palsy. It enhances the parent-child relationship for adopted and foster children, including children of foreign adoptions, especially those who come from institutions or confront terminal illness. It provides relief, stimulation, relaxation, bonding and attachment for the child (Bell, 2010).

For all these reasons, it could be said, without even a minimal reservation, that children need positive touch in their lives, especially in their early childhood settings. Such touch is essential to form strong bonds between infant and caregiver as well as to sustain health attachment throughout early childhood according to attachment theory (Cassidy, 1999). Positive touch is also a necessary component in communicating to children a sense of worth to themselves and building trusting relationships, at least in the lower grades (McCroskey, Richmond \& McCroskey, 2006). In addition to this essential emotional role, touch plays an equally important role in children's physical development. Recent brain research (Fabbro, 1991; Kandel, Schwartz \& Jesse, 1999) considers touch as a component, which is imperative for the development of a healthy, growing brain. Touch has also been shown to decrease incidences of childhood illnesses, and has been key to dynamic growth of premature infants. Touch is crucial, but is sadly missing from children's lives. This lack can be mainly attributed to a pervasive fear that touch can lead to or be misconstrued as sexual abuse (Carlson, 2002).

We have already seen touch benefits, especially to children. However, a new question has arisen, which needs an appropriate answer. Do all children or adult persons have a positive opinion for touch? How do they perceive touching behavior? The answer would normally depend on culture, gender, age, education, and some special qualities such as occupation, social status etc. Sometimes, a few persons seem to have an irritating response to touch. It is apt to their disorder/disease, which may be associated with touch. There are four main disorders/diseases that are most common, and these are the following:

Attention Deficit Disorder, also known as ADD, may occur to people of all ages. Basically, it makes the sense of touch much more sensitive to some people rather than to others. It can be caused when things aren't properly filtered through the brain. 
Another disorder is called Tactile Defensiveness, which can also be a problem for people of all ages. People with this disorder have a tendency to react negatively to the feel of touch and they possibly trigger anxiety or panic. Tactile defensiveness is a sensory modulation difficulty that results in an inability to tolerate touch stimulation. Infants who exhibit tactile defensiveness will often arch away from contact, have difficulty feeding, and have great difficulty in self-regulation. Conversely, they may insist on being held constantly, screaming if put down. Parents may suspect that something is unusual about their child's behaviour, but since the signs of sensory modulation problems are subtle, the child may go undiagnosed for years (Watson-Genna, 2001).

Tactile defensiveness is a type of sensory defensiveness, one aspect of sensory integration dysfunction. Under normal circumstances, our bodies respond to our environment in an appropriate manner by relying on sensations that we take in from the environment. However, when the way we experience these sensations is in some way unusual, the entire system is thrown off balance.

Although there are five "external" senses (sight, sound, taste, smell and touch) and two "internal" senses (vestibular - the movement sense; and proprioceptive - the sense of own body in space), for now, we'd like to focus on the tactile (touch) system, and how tactile defensiveness manifests itself.

The tactile system is divided to serve two functions: protective (e.g. it tells us when something is hot or sharp, etc.), and discriminative (e.g. it lets us know that things are rough or smooth, etc.). Protective reactions relate to our body's sense of urgency, or adrenaline reactions (also called "flight or fight"), and help us respond quickly to dangerous situations. Discriminative reactions simply help us learn more about our environment. The protective response is the default in children with tactile defensiveness (Watson-Genna, 2001). Even in a non-dangerous situation, that is, when a particular sensation ought to be perceived as discriminative, such children perceive what they are experiencing as threatening and react accordingly. Children with tactile defensiveness are always "on guard," and are unable to perceive regular tactile sensations in an unexaggerated, un-"adrenalined" way. We can see this response in children who will immediately lash out when getting their nails cut or their hair washed. These types of responses can also be delayed and amplified throughout the day culminating in a major meltdown by the time the children get home from school. Tactile 
sensitivities can involve being unexpectedly touched (tapped on the shoulder, for example), being bothered by certain fabrics and materials (including bedding and sleepwear), reactions to various textures touching the skin- like glue, clay and sand, and even revulsion at the feel of lumpy foods in the mouth (Schapiro, 2002).

Sensory Integrative Dysfunction is a neurological disorder usually found in kids. It makes people feel uneasy, have poor balance, and have under or over sensitivity to touch. The main cause is that there is a dysfunction in the central nervous system. And finally, Somatosensory Affectional Deprivation (SAD) Sydrome, which leads to antisocial behavior development. An occupational therapist trained in sensory integration disorders has the ability to identify and treat tactile defensiveness. This ability is often seen in the context of other sensory defensiveness, such as auditory (hearing) or olfactory (smell).

\section{More research on pedagogical perspective of touch}

We have seen so far the critical role of skin as a fundamental factor of tactile perception, which leads directly to touching behavior. This behavior constitutes one part of the nonverbal behavior spectrum and it is connected to touch, an important, well-known and vital habit, common in all species and human beings. We have also seen the critical and positive role that touch can play for children from a developmental and neuropsychological point of view. But, is there any pedagogical perspective of touch? The answer is absolutely "yes" because a teacher of children of any age can use touch as a pedagogical strategy for classroom interactions instead of using commands (Bertsch, Houlihan, Lenz \& Patte, 2009). Other researchers have already shown that affectionate touch improves bonding and attachment relationships between teachers and children (Cigales, Field, Hossain, PelaezNogueras \& Gewirtz, 1996; Frymier \& Mongeau, 1997; Wellman, Phillips \& Rodriguez, 2000). In this way, they can both feel better and improve mutual understanding than when they keep physical distances from other people, because proximity and touch are two of the most important factors to construct trustful, friendly, anti-biased and cooperative perceptions and relationships with others (Kodakos \& Polemikos, 2000).

Moreover, proximity and touch reflect positively to academic, personal and social ability of any child. Field (2001), after conducting a study at the U.S.A. Touch Research Institute Nursery School environment has concluded that the teachers touched the children 
very little, particularly as the children grew older. These results point out that teachers living in a really touch-deprived society, such as the U.S.A., consider touch as a prohibited behavior. However, this is a phenomenon also met in societies other than the U.S.A.

Similar empirical research, carried out in the Greek nursery school environment, has concluded that Greek nursery school teachers usually avoid touch and touching behavior in general, in spite of the fact they are aware of and recognize the pedagogical usefulness of touch (Stamatis, 2005; Stamatis \& Kontakos, 2008). To be more specific, the research was developed on two levels. Initially, every nursery school teacher was asked to answer a questionnaire through which they could express their perceptions about touching behavior between them and the children in every day classroom interaction involving nonverbal communication behaviors. On a second level, was videotaped and video-analyzed touching behavior between teachers and children during nursery classroom environment interaction, focusing on specific touching behaviors, such as touched body point, touching duration, purpose and effectiveness of communication. All of them were examined under the prism of nonverbal communication aspects such as proxemics, paralinguistics, facial expression, posture, etc. Also examined was the way the aforementioned factors could contribute to the achievement of classroom pedagogical atmosphere, as well as the way these factors form the tactile communication context between nursery school teachers and children. Moreover, when nursery school teachers were asked to explain their reluctant behavior, they were not only unexpectedly surprised to be informed about this, but they also insisted on their belief of really touching the children very much. From all the above, it can be concluded that the nursery school teachers' views about touching the children were in juxtaposition with the results of the observation and analysis of their recorded teaching procedure. There are a few reasons for such teacher behavior, and these reasons are, usually, very complicated.

Moreover, in a subsequent research work carried out in June 2009, the investigation continued in order to determine whether or not the use of touching behavior is a valuable teaching strategy that can help improve the interactions between pre-school teachers and children into the pre-school classroom. In the frame of this research were trained twenty preschool teachers to give more positive touching behavior to kids, in their classroom environment such as approaching, caressing the head or hugging more than in the past. The findings of this empirical research data that were videotaped and vinteoanalyzed, highlight the improvement of the school climate and the interpersonal relationships between pre-school 
teachers and preschoolers. From this research, Stamatis (2009) concluded that teachers and children felt more comfortable, experienced less insecurity and developed their expressive and communicative skills.

\section{Conclusions}

In spite of all this, touch has a pedagogical perspective as a basic element of nonverbal communication. Anyone involved in curriculum design procedures should consider touch a necessary component for the development of a nonverbal communication context, keeping in mind that this could constitute a generous contribution to classroom interactions and modern teaching methods in education.

According to attachment theory and international research, an appropriate touch activates neuropsychological factors and contributes to reduce negative thoughts and feelings among the members of the educational community, normalizing interpersonal relationships. Certainly, under certain conditions, it might become very useful in the future for teaching and learning interactions or the educational environment. Our results confirm the findings of a wide body of existing research in Greek pre-school educational environment. 


\section{References}

Bell, D. C. (2010). The Dynamics of Connection: How Evolution and Biology Create Caregiving and Attachment. Lanham MD: Lexington.

Bertsch, K. M., Houlihan, D., Lenz, M. A. \& Patte, C. A. (2009). Teachers' commands and their role in preschool classrooms. Electronic Journal of Research in Educational Psychology, 7(1), 133-162. Available on www.investigacionpsicopedagogica.org/revista/articulos/14/english/Art_17_245.pdf. Retrieved $25^{\text {th }}$ of October, 2011.

Bugental, D. B., Ellerson, P. C., Rainey, B., Lin, E. K. \& Kokotovic, A. (2002). A Cognitive Approach to Child Abuse Prevention. Journal of Family Psychology, 16(3), 243-258.

Bushnell, E. W. \& Boudreau, J. P. (1993). Motor Development and the Mind: the potential role of motor abilities as a determinant of aspects of perceptual development. Child Development, 64, 1005-1021.

Carlson, F. M. (2002). Incorporating Touch in Early Childhood Settings. Available on www.carlsoncastone.pdf . Retrieved $5^{\text {th }}$ of December, 2007.

Cassidy, J. (1999). The Nature of a Child's Ties. In, J. Cassidy \& P. R. Shaver, (eds.), Handbook of Attachment: Theory, Research and Clinical Applications (pp. 3-20). New York: Guilford Press.

Cigales, M., Field, T., Hossain, Z., Pelaez-Nogueras, M. \& Gewirtz, J. (1996). Touch among Children at Nursery School. Early Childhood Development and Care, 126, 101-110.

Elias, L. \& Saucier, D. (2005). Neuropsychology: Clinical and Experimental Foundations. NY: Allyn \& Bacon.

Fabbro, F. (1991). The Bilingual Brain: Cerebral Representation of Languages. Brain and Language, 79(2), 211-222.

Field, T. (1999). Preschoolers in America are touched less and are more aggressive than preschoolers in France. Early Child Development and Care, 151, 11-17.

Field, T. (2001). Touch. NY: The MIT Press.

Frymier, A. B. \& Mongeau, P. A. (1997). Communicating with touch in the Teacher/Student Relationship. Annual Meeting of the Eastern Communication Association. Baltimore 10-13 of April, 1997. Available on www.eric.ed.gov/PDFS/ED427378.pdf . Retrieved $14^{\text {th }}$ of October, 2010. 
Granit, R. (1975). Receptors and Sensory Perception: A Discussion of Aims, Means, and Results of Electrophysiological Research into the Process of Reception. London: Greenwood Press Reprint.

Harris, J. A., Petersen, R. S. \& Diamont, M. E. (1999). Distribution of tactile learning and its neural basis. Psychology, 96, 7587-7591.

Hatfield, R.W. (1994). Touch and human sexuality. In, V. Bullough, B. Bullough \& A. Stein, (Eds.), Human Sexuality: An Encyclopedia (pp. 178-192). N.Y.: Garland Publishing.

Jourard, S. (1966). An Exploratory Case of Body - Accessibility. British Journal of Social and Clinical Psychology, 8, 222-231.

Kandel, E. R., Schwartz, J. H. \& Jesse, T. M., (1999). Neuroscience and behavior. HeraclionGR: Creta University Press.

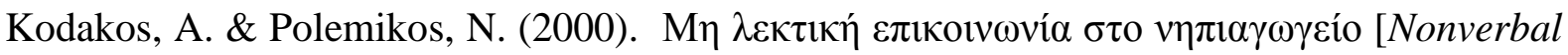
communication in kindergarten]. Athens, GR: Ellinika Grammata.

Lederman, S. J. \& Klatzky, R. I. (1987). Hand movements: a window into haptic object recognition. Cognitive Psychology, 19, 342-368.

McCroskey, J. C., Richmond, V. P. \& McCroskey, L. L. (2006). An introduction to communication in the classroom. The role of communication in teaching and training. USA: Pearson, Allyn \& Bacon.

Montagu, A. (1994). Interview to M. Mendizza. Published in Touch the future. In Birth and the origins of violence: one perspective. Available on www.birthpsychology.com/violence/montagu.htm. Retrieved 14th of June, 2005

Prescott, J.W. (1990). Affectional bonding for the prevention of violent behaviors: neurobiological, psychological and religious / spiritual determinants. Violent Behavior. Great Neck, NY: PMA Publishing.

Richmont, V. P. \& McCroskey, J. C. (2000). Nonverbal Behavior in Interpersonal Relations. NY: Allyn \& Bacon.

Schapiro, Z. (2002). A Touchy Problem: Tactile Defensiveness. Available on www.machonrakefet.co.il/tactile.htm. Retrieved 10th of April, 2006.

Simonds, C.J. \& Cooper, P.J. (2011). Communication for the classroom teacher. Pearson, Allyn \& Bacon.

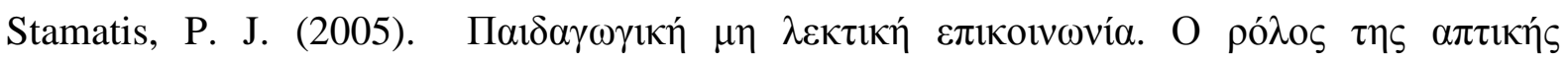

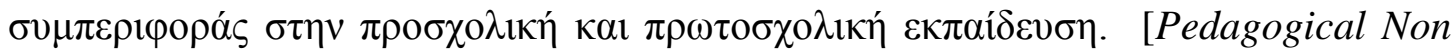


Verbal Communication. The role of tactile behavior in pre-school and first-school education]. Athens, GR: Atrapos.

Stamatis, P. J. \& Kontakos, A. (2008). Tactile behavior of Greek preschool teachers. Electronic Journal of Research in Educational Psychology, 6(1), 185-200. Available on www.investigacion-psicopedagogica.org/revista/articulos/14/english/Art_14_238.pdf.

Retrieved $17^{\text {th }}$ of April, 2009.

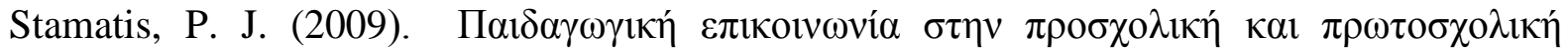
$\varepsilon \kappa \pi \alpha i \delta \varepsilon v \sigma \eta$. [Pedagogical Communication in pre-school and first-school education]. Athens, GR: Atrapos.

Watson-Genna, C. (2001). Tactile Defensiveness and Other Sensory Modulation Difficulties. LEAVEN, 37(3), 51-53.

Wellman, H.M., Phillips, A.T. \& Rodriguez, T. (2000). Young children understanding of perception, desire and emotion. Child Development, 71(4), 153-168.

Zillmer, E. A., Spiers, M. V. \& Culbertson, W. (2007). Principles of Neuropsychology. New York: Wadsworth Publishing. 